\title{
A Study of Self-development of EFL Teachers in the Universities of Sichuan Province in China
}

\author{
Lina Guan \\ Foreign Language Department, Sichuan University of Arts and Sciences, Dazhou City, Sichuan Province, China

\begin{abstract}
The quality of foreign language college English teachers will affect the quality of college English teaching. This article investigated 80 college foreign language teachers of SiChuan Province and writer found college English teachers had great pressures. They were eager to get the in-service training and they should be taught how to have self-development. Teachers should co-operate each other and break the isolation among them.
\end{abstract}

Index Terms — self-development, in-service training, self-reflection, teachers' burnout

\section{INTRODUCTION FOREWORD}

\section{A. The Necessity of EFL Teachers'Self-development}

Now in ELT many educators advocate "learner autonomy". When the focus is more moved to students, the roles of foreign language teachers are also changing. Gardner and Miller (2002) say teachers will become counselor, assessor, evaluator, materials developer, manager ,administrator and organizer and students become planner (of own learning), assessor (self and others), evaluator of motivator (of self), administrator (of own learning), organizer (of own learning) and advisor (to other learners).

ShuDingFang (2006) believes Chinese language teachers should change the traditional classroom teaching model, that is PPT model (Presentation, Practice and Production). Teachers should change the classrooms into places to supply students the utmost language input and places to keep students' studying interest and solve their difficulties. Appraisal of teachers' teaching should not be based on how much they finish teaching curriculums and how much teaching content they finish, but based on how much they can keep students' interest and supply them strategies to study by themselves. To realize this goal language teachers should develop themselves or have professional development. Teacher preparation - training, education, development - are seen by Wallace (1991) as three models, which he terms (a) the "craft" model, where a range of practical techniques is learned from an experienced person; (b) the "applied" model, implying a one-way application, and often therefore separation, of theoretical research to practice; and (c) the "reflective" model, with the teacher as a "reflective practitioner". If they don't have the sustainable development in teaching, the fossilization of teaching is easy to appear.

\section{B. The Current Situation of EFL Teachers in Sichuan Province}

Chinese language teachers have qualities in three aspects: the knowledge of English discipline, the knowledge of Education discipline and the noble spirit of devotion to teaching. Many of them need to develop in experience and change teaching attitude and many of them don't have the systematical training of theories and their teaching is lack of the supply of theoretical research. According to researches of many experts in recent years (XinGuangQin, 2006) Chinese language teachers have the following problems. Their working condition is not good; their work is overload; the structure of professional titles is not reasonable; little research is done in teaching; the chances to get in-service are quite few; their teaching beliefs need to be changed, and etc. These problems mainly focus on self-development, theoretical training and reinforcing abilities of applying knowledge.

Sichuan Province is in south-west of China and the economy doesn't develop as well as the eastern provinces. Teachers get few chances to study further and have few channels to know the latest teaching theories and teaching methods so the investigation about their in-service training, pressure and the ways how to get the self-development is quite urgent.

\section{The Purpose of the Research}

The writer spent three months using questionnaires to investigate the problems of teachers in Sichuan Province in order to know whether they have the same puzzles and difficulties as the teachers in other provinces and try to find the way-out for them. This article tries to explore in which ways teachers can develop themselves and improve teaching quality. By questionnaires and the open-ended questions the writer has investigated and analyzed what universities teachers need and what difficulties they have during teaching. Writer also provides some useful ways to make teachers have self-development, including the reflective teaching, the action research, diaries studies, exploratory practice and teacher' research etc. 


\section{SURVEY}

\section{A. Purpose of the Survey}

The writer used a detailed questionnaire developed specially for the purpose of the investigation. The investigation explores college English teachers' knowledge for teaching, the abilities for teaching, their pressures in teaching, their in-service training which are closely connected with teacher's self-development and tries to find the ways how to have reflective teaching and self-development in teaching.

\section{B. Subjects}

The participants include eighty English teachers from four universities in SiChuan Province: China West Normal University; Southwest China Electronical University of Science and Technology; SiChuan University of Arts and Sciences and ChengDu University of Science and Engineering. Teachers include ones teaching English major lessons and ones teaching non-English major lessons.

\section{Instruments}

The investigation is divided into two parts. In the first part the questionnaire is used. In the second part the participants are asked by the open-ended questions. The questionnaire is designed with the reference to the master's theses by Xia Jimei's (2002), Dai Jian-e's (2005) and Zhang Yanlin's(2005). The writer modified and increased some lists after interviewing some colleagues. There are thirty five investigated items and the questionnaire is written in Chinese in order to be finished easily. The questionnaire is divided into two parts: part one for investigating teachers' teaching knowledge and beliefs, teachers' pressures and burnout; part two for investigating teachers' in-service training and the ways to improve their teaching. Participant finished it in one hour. The writer handed out eighty five questionnaires and eighty of them were valid. The open-ended questions included two English questions and the time for finishing them is two days.

\section{Data Analysis}

For the statements with only one choice SPSS (statistical analysis software spss 12.0) was used to analyze them. For the statements with multiple choices, the writer collected the data and the calculator was also used.

\section{ReSUlT AND DisCUSSION}

\section{A. The Investigation of Questionnaire}

\section{Demographic information}

TABLE1.

DEMOGRAPHIC INFORMATION

\begin{tabular}{|c|c|c|c|}
\hline Items & & Frequency & Percent \\
\hline \multirow{3}{*}{ Gender } & Male & 38 & 48 \\
\hline & Female & 42 & 52 \\
\hline & Total & 80 & 100 \\
\hline \multirow{5}{*}{ Age } & Below30 & 30 & 38 \\
\hline & $30-39$ & 38 & 48 \\
\hline & $40-49$ & 8 & 10 \\
\hline & Over 50 & 4 & 4 \\
\hline & Total & 80 & 100 \\
\hline \multirow{5}{*}{ Degree } & B.A & 46 & 58 \\
\hline & M.A & 30 & 38 \\
\hline & Equivalent M.A & 4 & 4 \\
\hline & Doctorate & 0 & 0 \\
\hline & Total & 80 & 100 \\
\hline \multirow{5}{*}{ Professional title } & Assistant & 32 & 40 \\
\hline & Lecturer & 30 & 38 \\
\hline & Associate professor & 18 & 22 \\
\hline & Professor & 0 & 0 \\
\hline & Total & 80 & 100 \\
\hline \multirow{5}{*}{ Length of teaching } & Less than three years & 14 & 18 \\
\hline & $3-5$ years & 18 & 23 \\
\hline & $6-10$ years & 16 & 20 \\
\hline & More than 10 years & 32 & 39 \\
\hline & Total & 80 & 100 \\
\hline
\end{tabular}

In this part of the survey, it inquires about participants' gender, age, education background, professional titles and length of teaching years. According to the table above, 38\% of participants are male and 52\% are female; $38 \%$ are below 30; 39\% have worked more than ten years. 58\% have got the bachelor degree, 38\% have got the master degree and $4 \%$ have got equivalent master degree. It shows the diplomas of participants still need to be improved. $40 \%$ are assistants, $38 \%$ are lectures and $22 \%$ are associate professor. It shows the young teachers are the main force so their 
self-development is important for university English teaching.

2 Teachers' beliefs, and abilities, and pressures about college English teaching

TABLE 2.

THEIR PREFERENCE FOR THE PROFESSION

\begin{tabular}{lll}
\hline Preference & Frequency & Percent \\
\hline Liking & 36 & 45 \\
Medium liking & 32 & 40 \\
Not liking & 2 & 2.5 \\
Not knowing & 10 & 12.5 \\
Total & 80 & 100 \\
\hline \multicolumn{4}{c}{} \\
\multicolumn{2}{c}{ TABLE 3. } \\
\hline Willingness & THEIR WILLINGNESS TO TAKE UP THIS PROFESSIONAL A SECOND TIME \\
\hline Yes & Frequency & Percent \\
No & 32 & 39 \\
Not knowing & 20 & 25 \\
Total & 28 & 36 \\
\hline
\end{tabular}

As table 2 and table 3 indicate, $45 \%$ of participants have interest in teaching and $40 \%$ of them like teaching basically. When asked whether to continue the job of teaching if they have the second choice, $39 \%$ of participants give the positive answers and the small part of participants give the negative answers.

\begin{tabular}{|c|c|c|c|}
\hline \multicolumn{2}{|l|}{ Stress } & Frequency & Percent \\
\hline \multicolumn{2}{|l|}{ No } & 6 & 7.5 \\
\hline \multirow{5}{*}{ Yes } & Slight stress & 46 & 57.5 \\
\hline & Normal & 20 & 25 \\
\hline & Fairly intense stress & 8 & 10 \\
\hline & Excessively intense stress & 0 & 0 \\
\hline & Total & 80 & 100 \\
\hline \multirow{11}{*}{ Major factors leading to stress } & Factors & & \\
\hline & Students & 22 & 11.3 \\
\hline & Over workload & 26 & 13.4 \\
\hline & Interpersonal relationship & 8 & 4.1 \\
\hline & Poor working condition & 18 & 9.2 \\
\hline & Their own low proficiency & 20 & 10.3 \\
\hline & Research demands & 56 & 28.8 \\
\hline & Curriculum reform & 10 & 5.1 \\
\hline & Teaching demands & 10 & 5.1 \\
\hline & Promotion of professional titles & 24 & 12.3 \\
\hline & Total & 194 & 100 \\
\hline \multirow{6}{*}{ Effect of intense stress } & Low efficiency & 10 & 12.5 \\
\hline & In low spirits & 34 & 42.5 \\
\hline & Poor teaching performance & 12 & 15 \\
\hline & Ill health & 12 & 15 \\
\hline & Others & 12 & 15 \\
\hline & Total & 80 & 100 \\
\hline
\end{tabular}

As table 4 indicates, $57.5 \%$ of participants are slightly stressed and $25 \%$ are normally stressed. $24 \%$ of them suffer from fairly intense stress, $10 \%$ from excessively intense stress and only $8 \%$ have no pressures. Among the factors causing teachers' pressures in teaching, research demand is the first main reason, over workload is the second main reason and the promotion of professional title is the third. When asked the main influence brought by the pressures, $42.5 \%$ of participants think they will be in low spirits. When asked how to deal with the low spirits, participants have mentioned the following ways: playing, doing sports, resting and self-regulation, etc. It shows most of participants are under great pressure and heavy workload. It maybe explains why some teachers can't really like doing this job. 
TABLE 5.

MOST DISSATISFYING AND SATISFYING ASPECTS

\begin{tabular}{|l|l|l|l|}
\hline \multirow{5}{*}{$\begin{array}{l}\text { Aspects leading } \\
\text { to dissatisfaction }\end{array}$} & Aspects & Frequency & Percent \\
\cline { 2 - 4 } & Small income & 38 & 38 \\
\cline { 2 - 4 } & $\begin{array}{l}\text { Students are tough } \\
\text { to deal with }\end{array}$ & 18 & 18 \\
\cline { 2 - 4 } & $\begin{array}{l}\text { Inharmonious interpersonal } \\
\text { relationship }\end{array}$ & 0 & 0 \\
\cline { 2 - 4 } & Low social status & 8 & 8 \\
\cline { 2 - 4 } & $\begin{array}{l}\text { Unfavorable promotion of } \\
\text { professional titles }\end{array}$ & 20 & 20 \\
\cline { 2 - 4 } $\begin{array}{l}\text { Aspects leading to } \\
\text { satisfaction }\end{array}$ & Total stress & 16 & 16 \\
\cline { 2 - 4 } & Large income & 100 & 100 \\
\cline { 2 - 4 } & Students are promising & 2 & 2.1 \\
\cline { 2 - 4 } & $\begin{array}{l}\text { Harmonious interpersonal } \\
\text { relationship }\end{array}$ & 40 & 43.4 \\
\cline { 2 - 4 } & High social status and being respected & 16 & 17.3 \\
\cline { 2 - 4 } & Favorable promotion of PT & 10 & 10.8 \\
\cline { 2 - 4 } & Good working condition & 6 & 6.5 \\
\cline { 2 - 4 } & Total & 18 & 19.5 \\
\hline
\end{tabular}

TABLE 6.

DEGREE OF JOB SATISFACTION

\begin{tabular}{lll}
\hline Attitudes & Frequency & Percent \\
\hline Very satisfied & 0 & 0 \\
Satisfied & 16 & 20 \\
Comparatively satisfied & 36 & 45 \\
Not satisfied & 26 & 32.5 \\
Extremely dissatisfied & 2 & 2.5 \\
Total & 80 & 100 \\
\hline
\end{tabular}

As tables above show, the first three teachers' most dissatisfying aspects in teaching are the small income, $38 \%$; the unfavorable promotion of professional titles, $20 \%$ and the intense stress, $16 \%$. The first two teachers' most satisfying aspects in teaching is to teach students well, $43.4 \%$ and good working condition, 19.5\%. It shows college English teachers have the high sense of responsibility about teaching. When asked about the degree of job satisfaction, $45 \%$ of participants are comparatively satisfied and $32.5 \%$ of them are not satisfied.

TABLE 7.

PROBLEMS EXISTING IN TEACHING AND RESEARCH

\begin{tabular}{|c|c|c|c|}
\hline Problems & & Frequency & Percent \\
\hline \multirow{6}{*}{$\begin{array}{l}\text { Problems } \\
\text { existing In } \\
\text { teaching }\end{array}$} & Lack of appropriate materials available & 32 & 22.2 \\
\hline & Overcrowded class size & 30 & 20.8 \\
\hline & $\begin{array}{l}\text { Teaching students with different language } \\
\text { proficiency }\end{array}$ & 52 & 36.1 \\
\hline & Their own teaching abilities & 16 & 11.1 \\
\hline & No mentoring & 14 & 9.7 \\
\hline & Total & 144 & 100 \\
\hline \multirow{5}{*}{$\begin{array}{l}\text { Problems } \\
\text { existing In } \\
\text { research }\end{array}$} & Lack of appropriate materials available & 34 & 23.9 \\
\hline & No mentoring & 26 & 18.3 \\
\hline & Few channels & 38 & 26.7 \\
\hline & Their own research abilities & 44 & 30.9 \\
\hline & Total & 142 & 100 \\
\hline
\end{tabular}

As table 7 indicates, the first main problem existing in teaching is to teach students with different language proficiency, $36.1 \%$. The other main ones are the lack of appropriate materials available, $22.2 \%$ and overcrowded class size, $20.8 \%$. Now universities are easier to go into than before and students' levels are quite different so it is more difficult for teachers to teach them. The first main problem existing in research lies in participants' lacking research abilities, $30.9 \%$. Few channels are the second problem and the lack of appropriate materials is the third problem. So the young teachers need to consult more with the experienced teachers and learn from them.

TABLE 8.

THE MOST URGENT ISSUES TO DEAL WITH

\begin{tabular}{lll}
\hline Issues & THE MOST URGENT ISSUES TO DEAL WITH & Percent \\
\hline Increase of income & Frequency & 18.6 \\
Promotion of professional titles & 22 & 22 \\
Training for professional growth & 26 & 25.4 \\
Improvement of living condition & 30 & 11.8 \\
Improvement of working condition & 14 & 16.9 \\
Others & 20 & 5 \\
Total & 6 & 100 \\
\hline
\end{tabular}


As table 8 indicates, the first most urgent issue to deal with for participants is the training for professional titles, $25.4 \%$. The second most urgent issue is the promotion of professional titles, $22 \%$ and the third one is the increase of income. It shows participants hope to be given more chances to study further in order to do more researches if they want to get higher diplomas and professional titles.

TABLE 9.

THREE MOST DESIRED ITEMS

\begin{tabular}{lll}
\hline Items & Frequency & Percent \\
\hline Funds for scientific research & 28 & 12.7 \\
Mentored by experienced teachers & 24 & 10.9 \\
Promotion of professional titles & 54 & 24.5 \\
Teaching expertise & 10 & 4.5 \\
Training for professional growth & 52 & 23.6 \\
Scholastic attainment & 52 & 23.6 \\
Total & 220 & 100 \\
\hline
\end{tabular}

As table 9 indicates, when asked about the most desired items currently, most participants give priority to the promotion of professional titles, 24.5\%; training for professional growth and scholastic attainment, 23.6\%. The others are the funds for scientific research and the mentoring by experienced teachers. The teaching expertise comes last maybe most participants think now they are competent to do the teaching job .

TABLE 10.

WHAT DO YOU THINK EFL TEACHERS SHOULD DO?

\begin{tabular}{lll}
\hline Items & Frequency & Percent \\
\hline The only purpose is to teach well & 6 & 8 \\
Focus on more teaching than doing research & 48 & 60 \\
Focus on more doing research than teaching & 6 & 8 \\
Doing research and teaching are equal important & 20 & 24 \\
Total & 80 & 100 \\
\hline
\end{tabular}

TABLE 11.

HOW DO YOU THINK THE ROLES OF DOING RESEARCH, WRITING ARTICLES AND JOINING IN THE RESEARCH PROJECTS?

\begin{tabular}{lll}
\hline Items & Frequency & Percent \\
\hline Not to publish articles and think it's not important & 2 & 3 \\
To think it's important but not publish articles & 24 & 30 \\
To publish articles but think it's not important & 16 & 20 \\
To think it's important and publish articles & 38 & 47 \\
Total & 80 & 100 \\
\hline
\end{tabular}

TABLE 12.

THE PURPOSE TO PUBLISH ARTICLES OR JOIN IN THE RESEARCH PROJECTS

\begin{tabular}{lll}
\hline Items & Frequency & Percent \\
\hline To be interested in it & 8 & 10 \\
To improve the professional title & 50 & 63 \\
To satisfy need of requirement of jobs & 8 & 10 \\
To achieve in research field & 8 & 10 \\
The other & 6 & 8 \\
Total & 80 & 100 \\
\hline
\end{tabular}

As table 10 and table 11 and 12 indicate, $60 \%$ of participants think teaching is the first important and doing research is the second important. It shows although participants regard teaching as their duty and responsibility, doing research is still quite important for them. When asked whether they think doing research is important and whether they have published articles or joined in the research projects, $47 \%$ of participants think it is important and they have published articles, $30 \%$ of them think it is important but maybe due to their limited abilities or inadequate chances they can't publish articles. $63 \%$ of participants admit they publish articles because they must do it in order to get higher professional titles and only few admit they do it because of interest of getting achievements.

TABLE 13.

THE MAIN ROLE FOR EFL TEACHERS TO PLAY IN TEACHING

\begin{tabular}{lll}
\hline Items & Frequency & Percent \\
\hline To teach foreign language knowledge & 10 & 13 \\
To guide ways to learn foreign language & 24 & 30 \\
To train ability of foreign language & 56 & 70 \\
Total & 80 & 100 \\
\hline
\end{tabular}


TABLE 14.

THE MAIN ELEMENTS TO INFLUENCE THE QUALITY OF EFL TEACHERS

\begin{tabular}{lll}
\hline Items & Frequency & Percent \\
\hline Examination requirement & 34 & 18.8 \\
Teachers & 24 & 13.3 \\
Students & 36 & 20 \\
The system of education & 56 & 31.1 \\
The teaching materials & 26 & 14.4 \\
The other & 4 & 2.2 \\
Total & 180 & 100 \\
\hline
\end{tabular}

As tables above show, $70 \%$ of participants think their teaching is mainly to train students' foreign language ability and only $13 \%$ of them think their teaching is to teach foreign language knowledge. It shows most college English teachers have changed their traditional teaching beliefs and have turned the focus of teaching knowledge to the focus of training foreign language communicative abilities. When asked about the elements involved in affecting their teaching quality, the first three most important elements are education system, students and examination requirement. Participants think the current education system has some shortcomings and it needs to be improved and too much focus of CET examinations is another important element.

TABLE 15.

WHICH OF THE FOLLOWING ABILITIES DO YOU THINK YOU HAVE?

\begin{tabular}{lll}
\hline Items & Frequency & Percent \\
\hline Teaching ability & 72 & 22.9 \\
Ability for doing research & 34 & 10.8 \\
Ability to design curriculum & 18 & 5.7 \\
Ability to assess teaching & 12 & 3.8 \\
Ability to design examination & 20 & 6.3 \\
\hline Ability to have self-examination & 44 & 14 \\
Ability to teach students how to learn & 22 & 7 \\
Ability to have induction and generalization & 26 & 8.2 \\
Ability to do experiments & 8 & 2.5 \\
Ability to use computers & 30 & 9.5 \\
Ability to communicate and work in English & 28 & 8.9 \\
Total & 314 & 100 \\
\hline
\end{tabular}

TABLE 16.

CHOOSE THE MOST COMPETENT ABILITIES FROM THE FOLLOWING ONES

\begin{tabular}{lll}
\hline Items & Frequency & Percent \\
\hline Ability to teach in the classroom & 38 & 27.9 \\
Ability to answer questions & 10 & 7.3 \\
Ability to use heuristic methods & 40 & 29.4 \\
Ability to organize classroom & 16 & 11.7 \\
Ability to help students study in passive ways & 16 & 11.7 \\
Ability to teach challenging students & 6 & 4.4 \\
Ability to teach slower students & 4 & 2.9 \\
Ability to teach advanced students & 4 & 2.9 \\
The other & 2 & 1.4 \\
Total & 136 & 100 \\
\hline
\end{tabular}

When asked which ability is the best one in their teaching, the teaching ability, the self-examination ability and doing- research ability are the first best abilities. So teaching and doing-research are still the most important things for college English teachers. When asked about the best abilities in detail in their teaching, 29.4\% of participants choose the heuristic teaching, $27.9 \%$ of them choose the teaching ability in the classroom and $11.7 \%$ of them choose the ability to organize classroom and help students studying in passive ways.

\section{3 the investigation for in-service education}

TABLE 17.

THE TRAINING YOU HAVE ATTENDED IN RECENT YEARS

\begin{tabular}{lll}
\hline Items & Frequency & Percent \\
\hline To train for improving diplomas & 20 & 25 \\
To train for excellent teachers & 16 & 20 \\
To train for new teachers & 20 & 25 \\
To train for using computers & 16 & 20 \\
The other & 8 & 10 \\
Total & 80 & 100 \\
\hline
\end{tabular}


TABLE 18.

THE MAIN TRAINING YOU HAVE ATTENDED

\begin{tabular}{lll}
\hline Items & Frequency & Percent \\
\hline In-service training for a short time & 34 & 40.4 \\
To observe others' teaching & 30 & 35.7 \\
To attend training by correspondence & 8 & 9.5 \\
To do research on a special topic & 10 & 11.9 \\
To be trained to use computers & 2 & 2.3 \\
Total & 84 & 100 \\
\hline
\end{tabular}

When it comes to which kind of training participants have attended, the training for improving diplomas and the new teachers' training are both $25 \%$, the others are the training for the backbone teachers and computers. When it comes to the detailed training model, the short-term training does the first, 40.4\%; inspecting and learning from the other teachers goes the second, $35.7 \%$. The others are the training for special research projects and training for the correspondence courses. It shows the in-service short-term training for improving diplomas is important for college English teachers.

TABLE 19.

THE MAIN REASONS TO HAVE IN-SERVICE TRAINING

\begin{tabular}{lll}
\hline Items & Frequency & Percent \\
\hline To get a higher diploma & 30 & 26.3 \\
To finish tasks assigned & 4 & 3.5 \\
To get a higher professional title & 28 & 24.5 \\
To improve teachers' quality & 50 & 43.8 \\
To satisfy development of the college & 2 & 1.7 \\
Total & 114 & 100 \\
\hline
\end{tabular}

When asked why they attend these kinds of training, $43.8 \%$ of participants think it can enhance their quality, 26.3\% of them think it can improve their diplomas and $24.5 \%$ of them do it to get the higher professional titles. It shows most English teachers want to not only improve their teaching level but also their diplomas by attending training.

TABLE 20 .

THE DISADVANTAGES EXISTING IN PRESENT SYSTEMS OF IN-SERVICE TRAINING

\begin{tabular}{lll}
\hline Items & Frequency & Percent \\
\hline Content of training is out-of-date and forms are not new & 30 & 26.7 \\
Content of training is not practical and not helpful for teaching & 14 & 12.5 \\
Teachers can't attend in-service training often & 38 & 33.9 \\
The chances to attend training are few & 30 & 26.7 \\
Total & 112 & 100 \\
\hline
\end{tabular}

When it comes to the shortcomings of the current training, 33.9\% of participants say they can't often attend the training, $26.7 \%$ of them say they have few chances to attend the training and the content of training is too old to give the new ideas and beliefs so providing more chances for teachers is an urgent issue.

TABLE 21.

HOW DO YOU HAVE SELF-DEVELOPMENT IN YOUR TEACHING?

\begin{tabular}{lll}
\hline Items & Frequency & Percent \\
\hline To study and research by yourself & 58 & 46.7 \\
To discuss with your colleagues & 26 & 20.9 \\
To consult for experts or experienced teachers & 38 & 30.6 \\
The other & 2 & 1.6 \\
Total & 124 & 100 \\
\hline
\end{tabular}

TABLE 22.

THE BEST WAYS YOU LIKE TO HAVE SELF-DEVELOPMENT

\begin{tabular}{lll}
\multicolumn{3}{c}{ THE BEST WAYS YOU LIKE TO HAVE SELF-DEVELOPMENT } \\
\hline Items & Frequency & Percent \\
\hline One another's help and interaction among colleagues & 18 & 12.8 \\
To get higher diploma by in-service training or attending training by correspondence & 32 & 22.8 \\
To study and research by yourself & 30 & 21.4 \\
To attend in educational experiments or researching & 18 & 12.8 \\
To observe and study in other places & 42 & 30 \\
Total & 140 & 100 \\
\hline
\end{tabular}

When asked about the ways for participants to have self-development, $46.7 \%$ choose to study by themselves, $30.6 \%$ choose to consult with the experienced teachers or experts and only $20.9 \%$ choose to discuss with the other colleagues. $30 \%$ of participants' favorite ways to study is to go outside for visiting and observing the other teachers' teaching, $22.8 \%$ choose to study for short-term or attend the correspondence courses and $21.4 \%$ choose to study by themselves. It shows most college English teachers don't have the habit of co-operating one another in having self-development. 
TABLE 23.

THE MAIN WAYS THAT YOU HAVE HAD TO GET NEW INFORMATION

\begin{tabular}{lll|}
\hline Items & Frequency & Percent \\
\hline To use computers & 54 & 42.1 \\
To read magazines, newspapers and books & 60 & 46.8 \\
To watch TV & 10 & 7.8 \\
To discuss & 4 & 3.1 \\
Total & 128 & 100 \\
\hline
\end{tabular}

When asked about the ways to get the new information, $46.8 \%$ of participants choose to read academic magazines, books and newspapers, $42.1 \%$ of them choose to use the computers and only $3.1 \%$ choose to discuss one another. It shows reading academic books is the main way for them to get the new information.

TABLE 24.

HOW DO YOU THINK EFL TEACHERS WILL BE TRAINED?

\begin{tabular}{l|l|l}
\hline Items & Frequency & Percent \\
\hline To study teaching methods & 38 & 39.5 \\
To study how to do research & 38 & 39.5 \\
To study theories of cognition and studying & 16 & 16.6 \\
The other & 4 & 4.1 \\
Total & 96 & 100 \\
\hline
\end{tabular}

TABLE 25.

THE TIME THAT YOU ARE WILLING TO BE TRAINED

\begin{tabular}{l|l|l}
\hline Items & Frequency & Percent \\
\hline Three to five months & 14 & 18 \\
Half a year & 22 & 27 \\
One year & 20 & 25 \\
One or two years & 24 & 30 \\
Total & 80 & 100 \\
\hline
\end{tabular}

When talking about the focus of teachers' training, 39.5\% of participants think the methods for doing researches and teaching are the most important and these are the teachers' main focus. When talking about the time to attend training, $30 \%$ of participants want to study one or two years and $27 \%$ of them want to study for half a year. It shows teachers want to learn the really useful things in the long-term training.

TABLE 26.

HOW DO YOU THINK THE NECESSITY TO HAVE THE REFLECTIVE TEACHING?

\begin{tabular}{lll}
\hline Items & Frequency & Percent \\
\hline It's quite necessary & 32 & 40 \\
It's necessary & 44 & 55 \\
It doesn't matter & 4 & 5 \\
It's not necessary & 0 & 0 \\
It's not necessary at all & 0 & 0 \\
Total & 80 & 100 \\
\hline
\end{tabular}

TABLE 27.

DO YOU HAVE THE REFLECTIVE TEACHING?

\begin{tabular}{llll}
\multicolumn{3}{c}{ DO YOU HAVE THE REFLECTIVE TEACHING? } & \\
\hline Items & Frequency & Percent \\
\hline Yes & 46 & 58 \\
Occasionally & 32 & 40 \\
Not & 2 & 2 \\
Total & 80 & 100 \\
\hline
\end{tabular}

TABLE 28.

THE REASONS FOR YOU NOT TO HAVE THE REFLECTIVE TEACHING

\begin{tabular}{|c|c|c|}
\hline Items & Frequency & Percent \\
\hline It's not necessary & 4 & 5 \\
\hline Don't have the habit to do it & 28 & 35 \\
\hline Have no ways to insist on & 32 & 40 \\
\hline Don't know how to reflect it & 4 & 5 \\
\hline The other & 12 & 15 \\
\hline Total & 80 & 100 \\
\hline \multicolumn{3}{|c|}{$\begin{array}{l}\text { TABLE } 29 . \\
\text { HOW DO YOU HAVE THE REFLECTIVE TEACHING? }\end{array}$} \\
\hline Items & Frequency & Percent \\
\hline To write the reflective diary & 10 & 10.4 \\
\hline To read reference materials & 42 & 43.7 \\
\hline To ask for the solution from colleagues & 32 & 33.3 \\
\hline The other & 12 & 12.5 \\
\hline Total & 96 & 100 \\
\hline
\end{tabular}


When talking about their reflecting about their lessons, 55\% of participants think it is necessary to reflect and $40 \%$ of them think it is quite necessary to do it. $58 \%$ of participants say they will reflect their teaching and $40 \%$ of them say they will do it occasionally. $2 \%$ of them say they don't reflect it, when asked about the reason not to do it, $40 \%$ of participants say they can't insist on it and 35\% say they don't have the habits to do it and 5\% of them say they don't know how to do it. When asked about the ways to reflect their lessons, $43.7 \%$ choose to read the reference materials, $33.3 \%$ choose to turn to their colleagues for the solutions to the questions and only $10.4 \%$ choose to write the reflective diaries. It shows although most teachers have realized the importance to reflect their lessons some of them don't know how to reflect so they need to be trained to learn the ways to reflect their lessons.

TABLE 30.

DO YOU OFTEN COMMUNICATE WITH THE COLLEAGUES ABOUT THE FEELING OF TEACHING?

\begin{tabular}{lll}
\hline Items & Frequency & Percent \\
\hline Yes & 24 & 30 \\
Sometimes & 56 & 70 \\
No & 0 & 0 \\
Total & 80 & 100 \\
\hline
\end{tabular}

TABLE 31.

DO YOU THINK TEACHERS' MUTUAL COMMUNICATION AND INTERACTION WILL HELP TEACHERS' SELF-DEVELOPMENT?

\begin{tabular}{lll}
\hline Items & Frequency & Percent \\
\hline Yes & 70 & 86 \\
Don't know it & 2 & 4 \\
No & 8 & 10 \\
Total & 80 & 100 \\
\hline
\end{tabular}

When asked if participants will communicate with the other teachers about the understanding of their lessons, $70 \%$ of them say they sometimes do it and only 30\% of them give the definite answers to it. $86 \%$ of participants think communication among teachers is helpful for their self-development and only $10 \%$ of them give the negative answers to it. It shows most teachers have realized the importance of communication and help one another.

TABLE 32.

WHAT DO YOU THINK ARE THE BIGGEST OBSTACLE FOR TEACHERS TO HAVE CO-OPERATION?

\begin{tabular}{lll}
\multicolumn{2}{c}{ WHAT DO YOU THINK ARE THE BIGGEST OBSTACLE FOR TEACHERS TO HAVE CO-OPERATION? } \\
\hline Items & Frequency & Percent \\
\hline The difference of majors & 8 & 10 \\
The difference of time & 32 & 40 \\
Don't have this habit & 20 & 25 \\
Teachers close themselves because of competition & 20 & 25 \\
Total & 80 & 100 \\
\hline
\end{tabular}

When asked what are the obstacles existing in teachers' co-operation, $40 \%$ of participants say because their time-arrangement is not harmonious and $25 \%$ of them say they have no such habit and because teachers close themselves due to competition. It shows teachers are still not to be used to co-operating one another.

TABLE 33.

WHAT DO YOU THINK THE MOST EFFECTIVE WAYS TO ENCOURAGE TEACHERS?

\begin{tabular}{lll}
\hline Items & Frequency & Percent \\
\hline The encouragement of material & 30 & 27.2 \\
The encouragement of spirit & 16 & 14.5 \\
To be promoted by leaders & 6 & 5.4 \\
To give teachers the free space to develop their majors and themselves & 58 & 52.7 \\
Total & 110 & 100 \\
\hline
\end{tabular}

As table 33 indicates, $52.7 \%$ of participants think they should be given a freer and more harmonious space to develop their majors and develop themselves and $27.2 \%$ of them think they should be given material encouragement. It shows teachers long for a relaxing surrounding so they can be committed to developing themselves.

\section{B. The Investigation of the Open-ended Questions}

The open-ended questions are: (1) What plans will the participants finish in their teaching? (2) What aims should in-service programs achieve?

These open-ended questions require the participants to offer a few lines about the plans for their in-service education and the expectations of those education programs. When asked about the plan for professional growth and what aims should the in-service program achieve, participants give different answers. Here are some answers by participants.

About plans:

"I am preparing for the postgraduate entrance examination .I want to get a higher degree in order to get a higher professional title."

"I am majored in language and teaching methodology for postgraduate study and I have a good knowledge of those theories and can generate some novel ideas for doing researches. But because of the over workload, I can't do it. I hope 
in the following years, I can accumulate my teaching experiences and can efficiently allocate my time to teaching and researching, and conduct classroom research and make immense progress in my teaching and research."

"I am a young teacher and I hope some experienced teachers can guide me and give me really helpful suggestions to do research and write articles."

"I hope the dean can give the academic and financial support to help the young teachers to publish more articles to get a higher professional title."

"I hope to set aside some extra time to attain a higher degree. I shall distinguish myself at teaching and also research. The current issue is to decide on my research field and make an effort to achieve this goal."

About in-service education

"The young teachers have few chances to get the in-service training and I hope the leaders can give us more chances to get it."

"The programs should highlight some major points, not just impart some general theories, and the effectiveness should be stressed so that it can trigger changes in teachers as soon as possible."

"I hope the in-service education can really help improve teachers' qualities."

"I hope those programs can offer teachers chances to reflect on their own teaching, take into account the teachers' real needs, are designed for teachers' sake, provide the frontier theories and research, and can serve as a guideline for the classroom practice."

The answers show the young teachers especially have great pressure because they are faced with more problems than the old teachers, for example, to get a higher diploma; to get a higher professional title; to earn more money to support family, etc. $T$ The young teachers are eager to get the chances of in-service training and they are eager to get the help and support of coming from their schools or leaders. They need more freedom in carrying out their teaching.

\section{CONCLUSION}

\section{A. Major Findings and Discussion}

Based on the results and analysis above, this section discusses several issues arising from the survey.

Firstly, the participants are much confident of their teaching, but they lack confidence in doing research. They realize that they can do much better and should exert more effort to do research but their beliefs are not consistent with their behavior. Though realizing the importance of research, not many are conducting research. The fact can be traced to the following reasons. For one thing, teachers can't afford time for doing research because of the over workload; for another, many young participants lack the theoretical knowledge to do the researches. EFL teachers' abilities are not static but growing and changing and they include content, curriculum and teaching knowledge; the knowledge for second language acquisition and language learners; personal and practical knowledge, etc, so the youth participants need to study further. The investigation also indicates the participants have little co-operation one another and the professional isolation exits among them. They don't often communicate each other about their feeling and ideas of their teaching. They are easy to be limited in the reflection for their own classes and they can't see the other teachers' reflection. They are also limited in their own classroom.

Chinese EFL teachers have the rich teaching experience and the acute teaching awareness but their literature isolation prevents them from getting continuous professional development. Many teachers don't study and research the teaching theories systematically and they lack professional training to do the research and the necessary research technologies. It is related with the fact that EFL teachers have the heavy tasks and the great pressure so they should be provided the free context and be encouraged to share the resources in order to have the space to have self-development and time to have self-reflection.

Secondly, the participants are faced with the great pressure which is not good for teachers' development. The young teachers especially have great pressure because they are faced with more problems than the old teachers, for example, to get a higher diploma; to get a higher professional title; to earn more money to support family, etc. Teachers are easy to have burnout in their teaching under great pressure, which is fatigue or exhaustion; decreased motivation and efficiency, etc. Zemach(2006) points out in EFL burnout is triggered by the work of teaching, poor job conditions, or both. Teaching leads to burnout because of the following reasons: it attracts personalities drawn to burnout; most teachers work in isolation; the classroom interaction can be emotionally draining; there are physical demands; there is often a lack of emotional support from colleagues and supervisors. When salaries and working conditions are not rewarding, teachers need at least verbal recognition and praise. However, many programs aren't configured to allow that. How to prevent burnout is the important question to solve.

\section{B. Implication of the Survey}

LvLe (2006) points out that the disciplinary construction is the key for the sustainable specialty development. To achieve the goal of teacher development, university teachers need to be on the research team in order to devote themselves to the research in relevant disciplines and to share knowledge. Language teachers, to professionalize their language teaching, must engage in the academic research related to the courses they teach as well as the pedagogical research in terms of course content, learner study, teaching methodology, etc. The construction of the research team serves as an organizational frame work that guides teachers in their pursuit of higher professional goals. 
Teachers' self-development concerns many factors including society, universities and individual, etc. Universities should try their best to provide training programs for teachers and let everyone have the chance to join in it. Universities should have the good condition and good measures for teachers to have self-development. The measures should be carried out carefully and practically. The administrators should try their best to create the favorable environment for teachers and let everyone have the chance to join in it not just those few privileged ones, but to provide equal chances to all the staff. Universities should also provide the incentive policies to encourage them to do research and have innovation. Many teachers in the survey consider research as an essential ability of effective teachers, but they still need encouragement and support from the administration. Administrators should provide financial aid for teachers and provide channels for teachers to do research and publish their findings.

Penny Ur (1996) suggests some ways for FEL teachers to develop themselves which are useful for Chinese teachers. Informal discussions with a colleague with whom you feel at ease can contribute a lot to teachers' own development. Teachers can share their success and problems and discuss the new teaching ideas they have had. Teachers should often join the teaching meetings which mainly focus on teaching researches. Teachers can have appraisals and feedback can come from colleagues, students and self-appraisal. Read new ideas in magazines and try them out and make an agreement with a colleague to observe each other's lessons.

EFL teachers' research should be based on the classroom. The traditional class is the top-down curriculum, which means educators find the new teaching belief and teaching method then let teachers practice it in the classroom or teachers just teach according to the curriculum. If teachers can have teachers' autonomy, in which they reflect their teaching, find problems and solve them, this will become the down-up efficient ways to teach and it will make teachers get professional development. Foreign language teachers can have development by becoming teachers as researchers and turning foreign language teaching into an ongoing principled problem solving activity.

Chinese teacher education and teacher training system also need to be improved. The student teachers should learn the really useful knowledge which can help them a lot in their teaching career. Now some contents of this system are out of date and can't satisfy the demand of the society. Teacher training should not only teach them knowledge but should pay attention to their attitude and their insider view. Teacher cognition which is called the hidden teaching methodology should be paid attention.

\section{Limitations of the Research}

First, the survey is conducted mainly in the form of questionnaire which has not been proven to be valid or reliable. And due to the exploratory nature of the research, the questionnaire is primary descriptive. Second, the samples are mainly from four universities due to my limited resources and the number of the number of the samples is not big enough to make the survey more reliable.

\section{REFERENCES}

[1] College English Curriculum Requirement. (Teaching Programme). (2004). Department of Higher Education of Ministry Education issued to try out trial implementation in China in August.

[2] Dai jian'e. (2005). College English Teachers Education: Demand Analysis and Project Design. D. dissertation. Zhejiang University.

[3] Gardner, D. \& Miller, L. (2002). Establishing Self-Access From Theory To Practice. New York: Cambridge University Press.

[4] Jia aiwu. (2005). EFL Teachers Education and Professional Development Research. Foreign Language World, 1, 61-66.

[5] Jia guanjie. (2004). Applied Advanced Linguistics. Shanghai: Shanghai Foreign Language Education Press.

[6] Johnson,E. (2006). The Sociocultural Turn and Its Challenges for Second Language Teacher Education. TESOL Quarterly, 3 , 235-253.

[7] Li jie. (2006). Research on Knowledge and Skill of EFL Teachers. Foreign Language World, 4, 48-56.

[8] Liang zhongxian. (2004). New Trend of Development for Foreign Language Teachers in America. Foreign Language World, 6 , 58-62.

[9] Lv le \&Dai weihua. (2007). Key to Professional Development of EFL Teachers. Foreign Language World, 4, 22-27.

[10] McDonough,J. \& Shaw, C. (2004). Materials and Methods in ELT Second Edition A Teacher's Guide. Beijing: Beijing University Press.

[11] Richards, J \& Lockhart, C. (1996). Reflective Teaching in Second Language Classrooms. New York: Cambridge University Press.

[12] Scrivener, J. (2002). Learning Teaching A Guidebook For English Language Teachers. ShangHai: ShangHai Foreign Language Press.

[13] Shu dingfang. (2006).New Patterns for Foreign Language Teaching. Foreign Language World, 4, $21-29$.

[14] Wei li. (2005). New Method for Foreign Second Language Teacher Education. Foreign Language Teaching, 5, 51-54

[15] Xin guangqing. (2006). On Self-Development of College English Teachers. Foreign Language Teaching, 3, 18-23.

[16] Xia jimei. (2002). Research on EFL Teachers' Educational Concept, Knowledge, Skill and Scientific Research Current Situation. Foreign Language World, 5, 35-41.

[17] Yang huiqin. (2005). Demand Analysis for In-Service EFL Teachers' Professional Development. Foreign Language and Foreign Language Teaching, 8, 33-35.

[18] Zhang Yi \& Wang xin \& Guo wei \& Yu shen. (2003).Investigation of College English Teacher Quality. Foreign Language and Foreign Language Teaching, 10, 23-26.

[19] Zhang yanling. (2005). Research of Self-Development of Middle School English Teachers. D. dissertation. Central China 
Normal University.

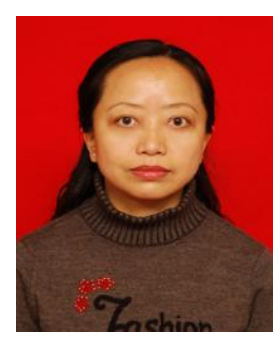

Lina Guan was born in Dazhou city, Sichuan province, China in 1972. She received her Master Degree in English Language Teaching from Western China Normal University, China in 2008.

She is currently an associate professor in the School of Foreign Language, Sichuan University of Arts and Sciences, Dazhou city, China. Her research interests include EFL acquisition and EFL teachers' development.

Ms. Guan is a member of Sichuan Province Social Sciences League in China. 